\title{
The development of institutional theory in the field of organization studies in Brazil ${ }^{1}$
}

\section{O desenvolvimento da teoria institucional no campo de estudos organizacionais no Brasil}

\author{
Edson Ronaldo Guarido Filho ${ }^{2}$ \\ Clóvis L. Machado-da-Silva ${ }^{3}$
}

\begin{abstract}
This article is based on the assumption that the construction of scientific knowledge is a social process characterized by the recursive dynamic between the social and intellectual dimensions. In light of this statement, we investigated how the construction of the institutional perspective is delineated in the context of organizational studies in Brazil from 1993 to 2007 , considering transformations in its substantive content as well as the social organization of scientists. The study is based on documentary research of published articles in scientific journals and at academic events. We analyzed social networks of authorship in order to map the cooperation relationships between researchers, and we also used scientometric analysis, based on cited and co-cited authors, for mapping the intellectual framework throughout the period under study. The findings reveal that social ties among scientists in the field of institutional theory are representative of intellectual affinity, which means that there are social mechanisms working in the process of diffusion of ideas and formation of shared understandings, both aspects regarded to social embeddedness of researchers in the clusters in which they belong.
\end{abstract}

Keywords: institutional theory, organizational studies, scientific knowledge, social mechanisms, social network analysis, scientometrics.

\section{Resumo}

Este artigo fundamenta-se no pressuposto de que a construção do conhecimento científico é um processo social, caracterizado pela dinâmica recursiva entre as dimensões social e intelectual. À luz dessa afirmação, investigamos como se caracterizou a construção da perspectiva institucional no âmbito dos estudos organizacionais no Brasil entre 1993 e 2007, considerando as transformações em seu conteúdo substantivo, bem como a organização social dos cientistas. 0 estudo apoia-se em uma pesquisa documental de artigos publicados em periódicos e eventos científicos. Foram analisadas as redes sociais de co-autoria, a fim de mapear as relações de cooperação entre pesquisadores, e também utilizamos a análise cientométrica, com base nos autores citados e co-citados, para mapear a estrutura intelectual ao longo do período em estudo. Os resultados revelam que os laços sociais entre cientistas no campo da teoria institucional são representativos de afinidade intelectual, o que significa que existem mecanismos sociais envolvidos no processo de difusão de ideias e formação de entendimentos compartilhados, sendo ambos os aspectos associados à imersão social dos pesquisadores nos agrupamentos de pertencimento.

Palavras-chave: teoria institucional, estudos organizacionais, conhecimento científico, mecanismos sociais, análise de redes sociais, cientometria.

\footnotetext{
Paper received in April 2010 and accepted for publication in June 2010.

${ }^{1}$ An earlier version of this article was presented at the 3rd Latin American and European Meeting on Organization Studies (LAEMOS) in Buenos Aires, Argentina in April, 2010. We are grateful to the audience at the seminar for their useful comments.

${ }^{2}$ Doutor em Administração pela Universidade Federal do Paraná, com concentração em Estudos Organizacionais e Estratégia em Organizações, e Professor do Programa de Mestrado e Doutorado em Administração da Universidade Positivo - PMDA/UP. Rua Prof. Pedro Viriato Parigot de Souza, 5300, Prédio da Biblioteca, 5a andar. Curitiba, PR, Brasil, CEP: 81280-330. Email: edson.guarido@gmail.com

${ }^{3}$ In memoriam - Doutor em Administração Institucional pela Michigan State University, com concentração em Estudos Organizacionais e Estratégia em Organizações, e Professor Titular da Universidade Federal do Paraná e do Programa de Mestrado e Doutorado em Administração da Universidade Positivo. Universidade Federal do Paraná - CEPPAD/UFPR e Universidade Positivo - PMDA/UP, Curitiba, PR, Brasil. Email clms@terra.com.br
} 


\section{Introduction}

Many studies have concentrated on understanding the construction of scientific knowledge by examining social relationships among researchers and the use of social co-authorship networks (e.g. ACEDO et al, 2006; BARABASI et al, 2002; LI-CHUN et al, 2006; LIU et al, 2005; MOODY, 2004; NEWMAN, 2001a; OTTE; ROUSSEAU, 2002; WAGNER; LEYDESDORFF, 2005). However, despite showing some evidence of knowledge sharing, these studies tend to be limited to the evidence of relationship patterns in scientific production and they have little to say with certainty on this matter without proper analytical depth. There are two reasons for this: the fact that one researcher works with another on a certain paper does not mean that there is a consistent intellectual alignment between them and, furthermore, researchers who have never had any direct contact with each other often share a common theoretical and analytical structure.

With this in mind, we investigated how the construction of the institutional perspective is delineated in the context of organizational studies in Brazil from 1993 to 2007, considering transformations in their substantive content as well as the social organization of scientists. Analytically, it is our belief that the construction of scientific knowledge is an ongoing social process comprehended by recursive dynamics between the social and intellectual dimensions. In this process, different social mechanisms are involved, such as relational, cognitive and political/intellectual mechanism.

The present article is partially supported by the findings we have previously published in two other articles. In the first, we traced the trajectory of the institutional perspective in the field of organizational studies in Brazil in terms of the collaboration networks of the researchers (GUARIDO FILHO; MACHADO-DA-SILVA; GONÇALVES, 2009). In the second, we investigated how the intellectual structure is conditioned by social relationships among researchers (GUARIDO FILHO; MACHADO-DA-SILVA; ROSSONI, 2010). Now, our interest is beyond an ordinary consolidation of these findings. While some results will be recovered, they will also be combined with complementary analyses in order to provide an integrated and dynamic view of the articulation of the social and intellectual dimensions, based on social mechanisms participating in the construction of scientific knowledge.

From the outset, we would like to make it clear that it is not our intention to discuss the trajectory of production in the field in terms of value judgment, but rather the social mechanisms involved in the construction of scientific knowledge. We believe that focusing these mechanisms may be of great value for understanding the relationship between structure and agency in this process, which is usually difficult to grasp in empirical procedures. Furthermore, our concern with emphasizing social mechanisms is justified due to the interest in institutional research, whose recent focus has been stressing the dimension of agency in processes of diffusion and institutionalization of organizational ideas, forms and practices, but also the structural conditioning concerning regulative, normative and cultural-cognitive dimensions.

This article has been organized into five sections in addition to this introduction. In the first, we consider the theoretical aspects on which the study is based, including theoretical assumptions, especially concerning the social and intellectual dimension in scientific knowledge and the notion of social mechanisms. We then provide details of the methodological procedures that support the empirical part of the study. The results of which are dealt with in subsequent section. We then discuss the results in light of the cognitive, relational and political/intellectual social mechanisms. In the final section, we present the conclusions and analytical implications for future studies.

\section{Theoretical framework}

The theoretical model for this study supports the idea that understanding the constitution of a specific body of scientific knowledge, such as the institutional perspective, involves social process of the production of scientific knowledge. Therefore, we understand that it is necessary to discuss the mutual influence of these aspects concerning social activity and those related to substantive content, which we define respectively as the social and intellectual dimension. Moreover, a perspective of analysis in this sense might be characterized by an epistemological nucleus, shared to a certain extent by actors in a scientific field who could identify each other 
as integrating an intellectual group. Eventually, those groups act in favor of its own legitimacy, the conditions of its reproduction in the field or the validation criteria for the knowledge produced.

Some considerations regarding these aspects will be given throughout this section in order to outline the relevant elements to the scheme of analysis of this work. Furthermore, we make brief comments on the basic theoretical framework used as a guideline to this article: structurationist approach, whereby the scientific field is considered a social system. At last, we discuss the notion of social mechanisms from the analytical viewpoint of this study.

\section{Social dimension}

The social dimension is closely linked to the organization and interaction of researchers or other social units during the activity of scientific production. According to Mullins (1973, p.18-19) ${ }^{1}$, there are several forms of collaboration in the scientific field: "(i) communication in the sense of serious discussion about ongoing research; (ii) co-authorship; (iii) the apprenticing, or mentoring, of a student by his or her teacher, and (iv) colleagueship (at the most basic level, two scientists working in the same laboratory)". However, for the purpose of this study, co-authorship has been considered for the mapping of collaboration networks among researchers, due to the fact it is the most formal and visible form of dealing with relationships between academics (ACEDO et al, 2006; CRONIN, 1995).

In academic literature, there are numerous works dedicated to describing or explaining the dynamics and social structure of a scientific field. Many of these have used social network analysis. For instance, through scientific collaboration networks, the influence of intermediaries in the frequency of collaboration between scientists was observed by Newman (2001a, 2001b). His results pointed to a relevant mechanism in the development of a scientific community, the phenomenon of small worlds. With a different focus, the collaboration relationship was also studied by Liu et al (2005), whose work stressed the impact of the structure of co-authorship among researchers on their productivity.

In Brazil, research in the scientific field through the analysis of cooperation networks found small worlds and center-periphery structures in different areas of research in management (e.g. MACHADO-DA-SILVA; ROSSONI, 2007; ROSSONI; GUARIDO FILHO, 2007, 2009; ROSSONI; GUARIDO FILHO; MACHADODA-SILVA, 2008). Moreover, the findings also showed that the formation of social capital and the stratification of scientific production favor more collaborative post-graduate programs, research institutes or researchers that acted as an intermediary between others.

\section{Intellectual dimension}

While the social dimension pays attention to social relations among the actors in a scientific field, the intellectual dimension focuses on the substantive content, objectified in the scientific production and shared by a group of researchers who adopt it as a valid theoretical framework for scientific practice. In this sense, it is closely linked to scientometry, a scientific field based on the conception of science as a measurable multidimensional construct. According to Van Raan (1997), scientometry is concerned with the understanding of socio-organizational processes and knowledge structures of the scientific field. Small (2004, p.72) explains: "when scientists agree on what constitutes prior relevant literature, including what is significant in that literature, they are in fact defining the structures of their communities". However, the measures and procedures in scientometrics are based predominantly on quantitative and bibliometric methods, providing an instrument for studies in the field of the sociology of science, especially through the analysis of citations and co-citation (LEYDESDORFF, 2001; VAN RAAN, 1997).

As discussed by Merton (1996), under the normative structure of communication system science, knowledge property and peer recognition are intrinsically associated to the act of publishing and the social practice of citations (SMALL, 2004). Citations "are much more than baubles dangling from the tails of scholarly texts; they testify to authors' common understanding of the bases on which recognition, rights, and rewards are dispensed and managed in contemporary science" (CRONIN, 2004, p.43). Nevertheless, Leydesdorff (1998, p.9) emphasizes the multidimensional nature of citations, stating that they are "the result of the interaction 
between networks of authors and between networks of their communications". And he follows: "It can function in scientific practices by indicating both the cognitive and the social contexts of a knowledge claim. At a generalized level, citations, as potentially repeated operations, sustain communication in the sciences by drawing upon cognitive and social contexts" (LEYDESDORFF, 1998, p.9).

On those basis, co-citation analysis stand as landmark in the development of the representation of knowledge domains (MOYA-ANEGÓN et al, 2006), because it is assumed that co-citation reveals the existence of intellectual relationships between authors that are cited together (CHEN; PAUL, 2001; SMALL, 1973; VARGAS-QUESADA; MOYA-ANEGÓN, 2007). These domains are partial maps of the intellectual structure of a scientific field and can be interpreted as consolidated or prominent sets of specialized knowledge that serve as a basis for research (READER; WATKINS, 2006), contributing to understand the dynamic of the transformation of scientific knowledge.

\section{Structuration of scientific knowledge}

In agreement with Machado-da-Silva, Fonseca and Crubellate (2005), we adopted an ontological view based on intersubjectivity, according to which the sharing of meaning among social actors guarantees localized objectivity, both spatially and temporally delimited, and in this sense more suitable to the assumption of recursiveness between structure and agency. Thus, the researcher is understood as an agent that is capable of acting with a purpose and influencing the structure of knowledge available in the field (FLIGSTEIN, 2001, 2008). Furthermore, we understand that this aspect is linked to the interpretation, as a capacity for reflexive monitoring by the social actor to cognitively process and attribute meaning to scientific stimuli under the conception of bounded rationality (MACHADO-DA-SILVA; FONSECA; CRUBELLATE, 2005). However, in accordance with Giddens (1984), priority is not given to individual agency but rather to the reciprocity between social actors who, through their interaction, construct and reconstruct the social systems in which they are involved. This process takes place through social practices that access the available reference frameworks (structures) resulted from this social activity. As we have stated elsewhere, "the action of researchers producing, interpreting and mobilizing themselves for their ideas are the object of research in light of the conditions of their academic organization and objectified knowledge, which are in turn a medium and outcome of scientific activity. [...] The knowledge produced through scientific activity [...] represents a certain world view which, when shared, influences interpretation and, therefore, the understanding of the phenomena under study" (GUARIDO FILHO; MACHADO-DA-SILVA; GONÇALVES, 2009, p.301).

Thus, our concern in the investigation of the institutional perspective in organizational studies is oriented to the intermediary processes, working on the construction of scientific knowledge, influencing the ways this perspective is presented both as a body of knowledge and as a community of interacting researchers.

\section{Social mechanisms}

Social mechanisms can be defined as social processes that help provide sociological explanations (HEDSTROM; SWEDBERG, 1996). As such, they are linked to the specification of explanatory elements that enable us to establish hypothetical connections between observable events: in this case, the understanding of the relationship between the social and intellectual dimensions, which implies researching, in light of the evidence, aspects both theoretically elaborated and subjacent to observed events (HEDSTROM; SWEDBERG, 1996). In this sense, dealing with social mechanisms enhances our understanding of how the relationship arises between the analytical categories under study beyond their description but without any intention of generalizing, in the sense of covering-laws models, since mechanisms do not comprehend deterministic causal models. In fact, social mechanisms are referred to as intermediary processes influencing the phenomenon under study (McADAM, 2003; DIANI, 2003a), so that its understanding is representative of the locally analyzed phenomenon (CAMPBELL, 2005; HEDSTROM; SWEDBERG, 1996).

Campbell (2005), following the work of Tilly (2001), compared the literature on social movements and organizational studies and proposed a common classification into three categories: (a) environmental; understood as external factors that affect actors' engagement for change (for instance, political activities); (b) cognitive, linked to the perception of identity, interests and perspectives on the part of the actors, positioning 
aspects such as framing, diffusion, translation and bricolage; (c) relational, linked to influences on capacity for relationship between actors and their networks, such as leadership and network cultivation.

\section{Methodological procedures}

As already mentioned in the introductory section, the present article recovers some of the data and findings previously presented in two other studies published by the authors (see GUARIDO FILHO; MACHADO-DASILVA; GONÇALVES, 2009 and GUARIDO FILHO; MACHADO-DA-SILVA; ROSSONI, 2010). However, our aim is not to make a compilation of results, but rather to construct a broader and integrated interpretive framework for the phenomenon of the construction of scientific knowledge. Thus, the procedures presented in this section in part reflect what had been done in those previous works, but also include an analysis that is supplementary to the framework of the research procedures.

The research design of this study is explanatory to the extent that its purpose is to understand the causal nexus subjacent to the constitution of the field of institutional theory in organization studies. This came about through the investigation of mutual influence between the social and intellectual dimensions and through interpretation based on social mechanisms. However, while these dimensions were also dealt with separately, there is some descriptive nature in the study, in that it focused, on the one hand, on characterization of the academic community in terms of its social organization (a social dimension) and, second, the preferences expressed in the form of cited authors and cited works, as well as knowledge structures that underlie the research related to the institutional perspective in organizational studies in Brazil (an intellectual dimension).

Data. Data were collected through the documentary research of scientific articles published in Brazilian scientific outlets over a period of fifteen years ranging from $1993^{2}$ to 2007 . The procedures for identifying and selecting the articles of interest involved: (i) an analysis of sources in order to identify articles of interest by analyzing their titles, abstracts, key words and introductory section, (ii) an electronic search of the websites of the consulted sources, and (iii) based on the partial results so far, an examination of the lattes curriculum of the twenty most prominent researchers in terms of published articles. These procedures allowed us to triangulate the data sources in order to ensure greater reliability regarding the selection of articles. Only articles with analytical focus guided by the theoretical framework of the institutional theory were selected, provided they were published in annals of congresses of the Brazilian Academy of Management [Anpad], (EnANPAD, EnEO e 3Es) in the fields of organizations and strategy or in scientific journals classified as "A National"3 by the Brazilian Governmental Accreditation Agency of Graduate Programs [CAPES], with an editorial line that converges with the field of organizational studies as classified in June 2007.

All the selected articles were coded and tabulated in order to construct an organized database. Authorship data extracted from the selected articles enabled the mapping of cooperation among researchers through coauthorship. Conversely, all the cited texts and authors listed in the bibliographic references of the selected articles were also tabulated and coded, which allowed us to analyze citations and co-citations.

After these steps, 297 articles had been selected, corresponding to the production of 256 researchers. As for references, out of a total of 10,445, we found that there were 4,625 citations of different works and 3,998 valid and distinct cited authors.

Based on these data, three stages of research followed, as explained below. The research method employed was quantitative and the data analysis was centered on the analysis of social networks, citation and co-citation, further complemented by the use of multiple regression techniques.

Stage 1: Evaluation of the expansion and the social organization. The expansion of the institutional perspective in the field of organizational studies was quantitatively evaluated through the (relative and absolute) volume of articles and researchers found for each year. The researchers were then classified as continuants, transients, newcomers, terminators or one-timers according to their regularity and distribution of work throughout the period as adapted from Braun, Glänzel and Schubert (2001) and Gordon (2007). 
Social organization of the academic community was represented by the construction of co-authorship networks in accordance with Liu et al (2005) and Moody (2004). For this purpose, we first constructed a two-mode matrix of incidence between articles and their respective authors. This was then transformed into a one-mode square matrix of authors, in which each cell indicates the occurrences of different pairs of co-authorship. Graphically, this illustrates the co-authorship network for scientific production of the field under study. In it, each node represents a single author and the ties indicate co-authorship relations at some time during the period under study. Moreover, each group in which researchers are connected to one another is a component, each configuring different spaces for relationships (WASSERMAN; FAUST, 1994).

Stage 2: Analysis of citations and co-citation. To analyze the cited authors we evaluated their prominence by counting the citations each received in published articles during the period under study. Co-citations were analyzed in accordance with Chen (2006). First, the frequency of co-citation was determined for each pair of authors cited together, whose data were compiled in a raw co-citation matrix. This matrix was then converted into a similarity matrix, standardizing the co-citation counts in accordance with Chen (2004) and VargasQuesada and Moya-Anegón (2007). This results in an author co-citation network, in that the greater the similarity coefficient between two cited authors, the closer they will be placed on the network, showing that they are co-cited with a very similar set of authors (READER; WATKINS, 2006). After that, the similarity matrix was redimensioned through exploratory factor analysis, according to the main components method with varimax rotation. We used the scree plot graphical analysis to define the number of factors whose labels were defined from the analysis of the cited authors with higher factor loading. The extracted factors helped us to identify intellectual groupings and were also represented in co-citation networks in the form of node attributes. This procedure was conducted for the two largest components of researchers in the field, involving different analytical periods, each originating specific co-citation networks; when compared, these allowed us to identify tendencies and discontinuities in the intellectual development of the field.

Stage 3: Relationship between the social and intellectual dimensions. The analysis of the relationship between the social and intellectual dimensions were conducted through the following procedures: (1) construction of the intellectual affinity network; (2) evaluation of the strength of social embeddedness on the intellectual structure, considering in the aggregate the social ties between the different groups of researchers; (3) evaluation of the strength of direct relationships (dyads) between researchers on the intellectual structure. For each of these procedures, we considered only the five largest components of the social network of researchers. The reason for this was their representativeness both in terms of the volume of published articles and the involvement of researchers throughout the period under study.

Construction of the intellectual affinity network. The intellectual affinity network is configured as a relational structure that no longer expresses social co-authorship. Unlike what was done in the first stage of this study, the intellectual affinity network is based on the similarity between researchers concerning the references they cite. Graphically, the more similar are the researchers, the closer they will be in the resulting network.

For this purpose, the two-mode matrix between researchers and cited authors was transformed into a square matrix and then into a similarity matrix of the researchers ${ }^{4}$. In the resulting network, we applied a variable attribute to each node, which enabled the identification of each researcher in relation of the component to which they belonged in the social co-authorship network. During this procedure, only the references shared between researchers were considered, which naturally eliminated those cited exclusively by one researcher. Furthermore, in order to reduce the density of the resulting network, we included only authors who had been cited at least eight times in the database. Thus, the resulting intellectual affinity network was based on a total of 331 cited authors.

Strength of embeddedness through ties. We used the E-I Index algorithm (KRACKHARDT; STERN, 1988) to evaluate the tendency of researchers in the same component to cite authors from the intellectual structure of this same component when writing a new article. The E-I Index allows a comparison between the proportion of ties within and outside the partitions, which correspond to the different components identified in the co-authorship network. Thus, values closer to 1 indicate a tendency towards external relationships with different components, while values closer to -1 show a tendency to establish internal relationships. The analysis was based on the 
intellectual affinity network and because the components originate from social groups, the ties between authors represent the degree of shared references.

Strength of direct relationships. For this purpose, we performed a Double-Dekker MRQAP multiple regression analysis that is normally used to test hypotheses based on dyadic relationships (DEKKER; KRACKHARDT; SNIJDERS, 2007). In general terms, through this procedure it is possible to evaluate whether one type of relationship influences another, which means a network regression analysis whose unit of analysis is no more the researcher, but the immediate ties between authors (HANNEMAN; RIDDLE, 2005). In the regression model, the intellectual affinity of researchers was the dependent variable and the dyadic co-authorship relationships were the independent variable, as stated in Guarido Filho, Machado-da-Silva and Rossoni (2010).

We used Ucinet 6 and Pajek 1.20 software to configure the co-authorship, co-citation and intellectual affinity networks. Ucinet was also used for the E-I Index algorithm and the MRQAP regression technique.

\section{Results}

The field of research in management in Brazil has seen significant growth especially since the last fifteen years. At least three contextual factors can account for this phenomenon: (i) the growing number of Master's Degree and Doctorate programs, (ii) the evaluation policy of post-graduate programs set by the responsible Brazilian agency (Capes), which has increased the importance of publishing scientific articles and (iii) the grater space for scientific communication with the rise of new congresses promoted by the Brazilian Academy of Administration (Anpad) since 2000 and the launching of new periodicals.

In keeping with this trend, the field of research based on institutional perspective has seen a sharp growth both in terms of the academic community and the number of articles being published. In this context, as we have recorded elsewhere, this growth has been accompanied by greater cooperation among researchers through coauthorship (see GUARIDO FILHO, 2008 and GUARIDO FILHO; MACHADO-DA-SILVA; GONÇALVES, 2009).

From here on, we will seek to answer our research purpose. We will first examine the social organization of researchers in order to examine the formation of local cognitive structures and interaction between the social and intellectual dimensions, which brings us to the discussion on social mechanisms involved in the construction of scientific knowledge.

\section{Social organization}

The production of articles based on the institutional perspective grew continually throughout the period under study. Since 1993, when the first texts were identified in the selected sources, until 2007, the number of articles grew consistently, as did the involvement of the academic community. Figure 1 shows the number of articles produced by year and the successive adherence of researchers to the institutional perspective to explain organizational phenomena. Every year, more researchers became involved in this type of work, showing that a specialized research field is gradually being constituted. 
Figure 1: Publications by year and the adherence of researchers to the institutional perspective

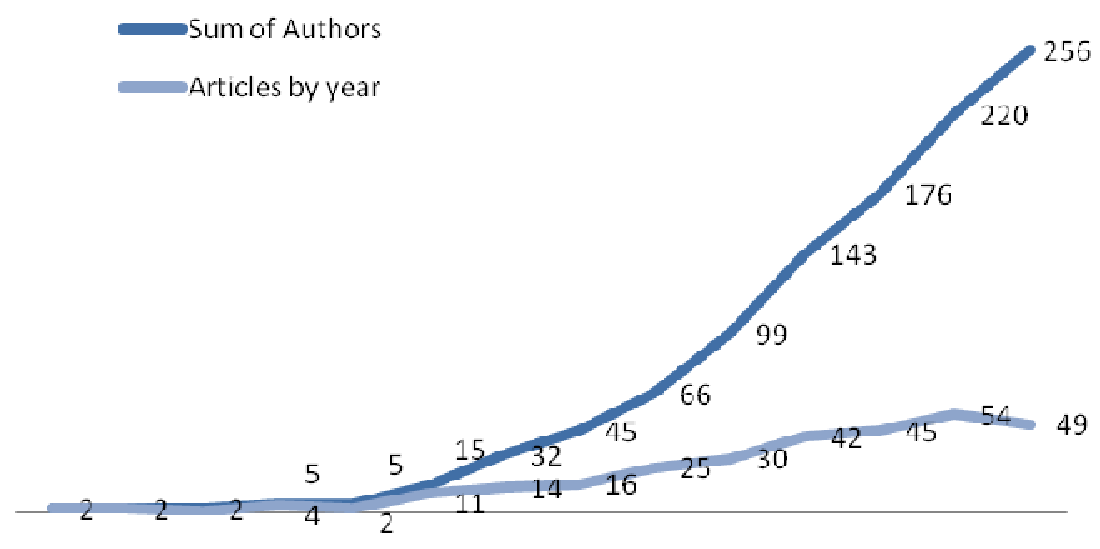

19931994199619971998199920002001200220032004200520062007

Source: research results.

However, this quantitative growth has come with a certain social organization among researchers, a result of greater collaboration in scientific production. Figure 2 shows the co-authorships for specific years.

In 2007, we observe a fragmented network made up of several small components and isolated authors (whose are not represented in the figure). These surround five larger components that together account for $48.1 \%$ of the network in terms of the number of authors. The largest, the main component, includes $20.3 \%$ of all the authors and $33.3 \%$ of the texts that were published during the period under study. The second largest component, in turn, has a lower number, with $14.5 \%$ of the total number of researchers and $24.2 \%$ of the articles that were written.

Figure 2: Configuration of the co-authorship network of researchers

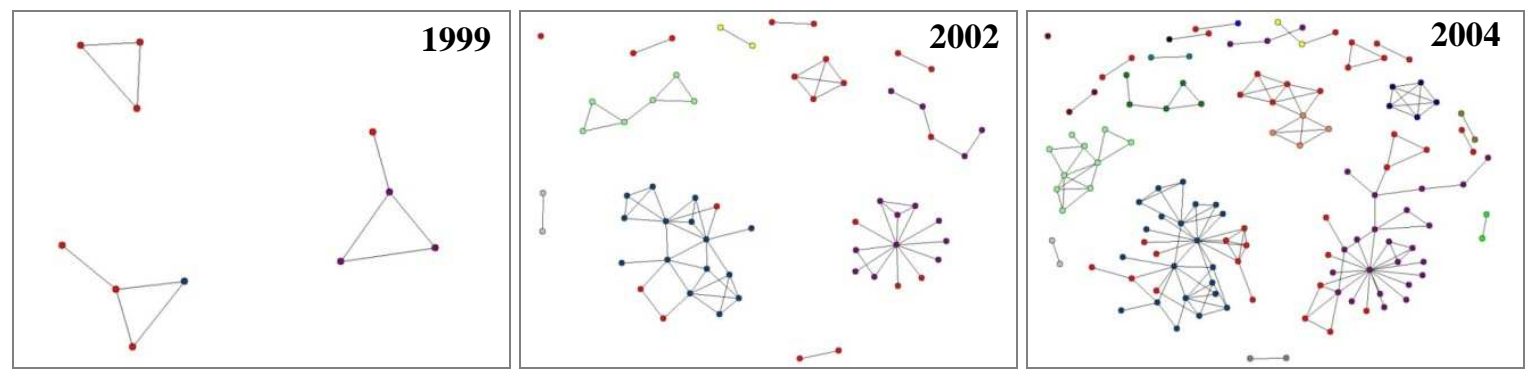




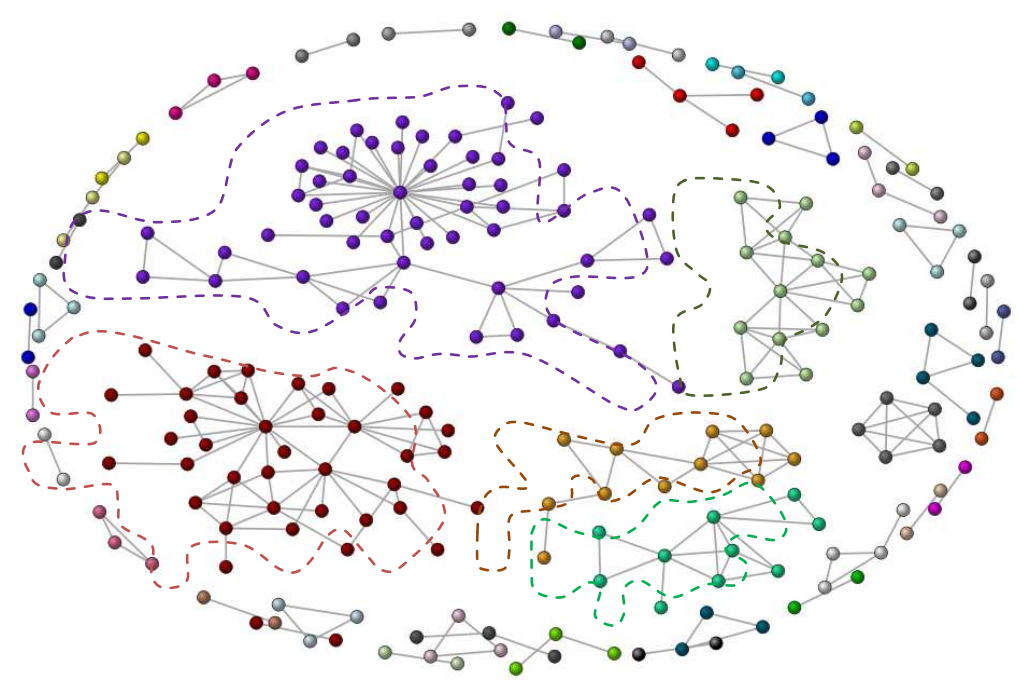

Note: The nodes in red are authors whose first publication occurred in the respective year of representation (up to 2006). Isolated nodes in the aggregate co-authorship network considering all the periods are not represented. Colors distinguish the components.

Source: research results.

Contrary to first impressions, the apparent disorganization of the network, although this is a characteristic of the field under study when observed globally, is related to a tendency towards a local agglomeration of nodes. This can indicate that inequality in formation of relationships could influence research practices and sharing of perspectives. As we pointed out elsewhere, "the presence of a network with few connections and with many small components suggests restricted communications between different parts of the network, which could be a tendency to form groups of researchers sharing different interests and preferences among themselves, whether epistemological, theoretical or thematic" (GUARIDO FILHO, MACHADO-DA-SILVA; GONÇALVES, 2009, p.307).

This fact becomes more interesting when we consider the influence of continuant researchers, those who are more regularly and frequently involved in the field in terms of scientific production. We found that the organized growth of the network, especially concerning the formation of the larger components, is closely linked to their activity in the field. Our findings showed that continuant researchers are the nodes with the larger degree, betweenness and flow centralities (see Figure 3). This means that: (i) they have more ties with other researchers, including less experienced ones, which shows stratification of relationships ${ }^{5}$; (ii) because relationships in the scientific field are also channels of intellectual influence (BORGATTI, 2005), the position of continuant researchers on the route of the collaboration relationship between the other authors influences the flow and content of information, and can affect other authors in how they conceive or conduct research that favors shared cognitive structures. 


\section{Figure 3: Centrality and relationships between categories of researchers}

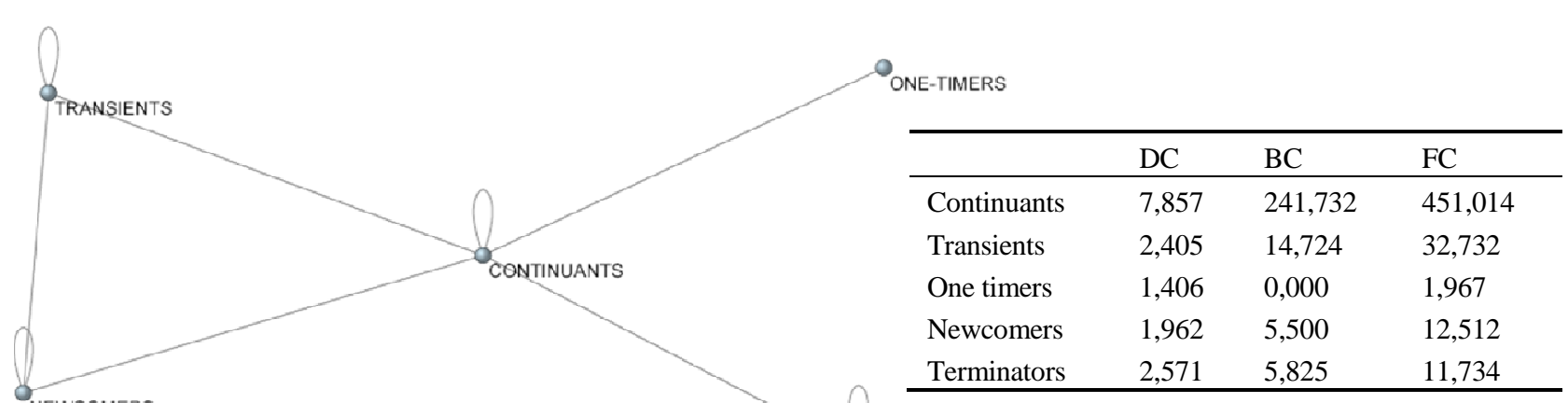

$\mathrm{DC}=$ degree centrality; $\mathrm{BC}=$ betweenness centrality; $\mathrm{FC}=$ flow centrality. The ties correspond to the image matrix resulting from the evaluation of the strength of the ties between categories and the density calculated for the overall connections between authors in the field. Only relationships whose density was greater than the density of the co-authorship matrix were considered.

Source: research results.

\section{Distribution of citations}

The distribution of citations among authors, considered as a whole, makes it possible to reflect on the bases of knowledge. This is because, on the one hand, the practice of citing is reflexive and at the same time necessary for scientific communication. As such, it is also conditioned by the social context. On the other hand, it is associated with values of scientific ethos providing conditions for the dynamic of reproduction involved in the (re)construction of scientific knowledge (LEYDESDORFF, 1998; MERTON, 1957).

The data collected showed a stratified distribution of citations, since of the 3,998 cited authors, around 57\% were cited only once, while only $4.8 \%$ were cited over ten times. The six most cited authors were: Scott, W.R. with 442 citations; Machado-da-Silva, C.L. with 417 citations, DiMaggio, P.J. with 361, Powell, W.W. with 337, Meyer, J.W. with 278 and Fonseca, V.S. with 274 citation. It is worth noting that the presence of two Brazilians, Machado-da-Silva and Fonseca, among the foreign authors considered classics in the field of organizational institutionalism could be an indication of the growing weight that Brazilian researchers have gained in the intellectual structure of the institutional perspective in the country. This is reinforced by the fact that three other Brazilian researchers also figure among the most cited authors, with between 150 and 100 citation each: Vieira, M.M.F. with 144, Carvalho, C.A.P. with 122 and Fernandes, B.H.R. with 115. The existence of authors who were cited far more often than the majority shows their prominence in the field, whether it is because they are considered legitimate cognitive resources and adequate for scientific production or because they are seen as conceptual symbols (SMALL, 1978). Moreover, all the authors mentioned above also figured among the cited authors with the highest h-index (HIRSCH, 2005), a bibliometric index that indicates their representativeness as a valid theoretical framework, which indirectly expresses their intellectual recognition by researchers in the field under study. Authors with greater academic recognition tend to be more influential and, therefore, have a greater impact on the knowledge generated in the practice of scientific production, in that they are also considered favorable resources for sustaining and validating the ideas stated in scientific articles (SMALL, 1978).

\section{Formation of local cognitive structures}

The characteristics of the co-authorship network of researchers interested in the institutional perspective in organizational studies raise questions as to how the knowledge is articulated in the different groups that were found. Considering that scientific collaboration may be a relevant indicator on social interaction in the 
construction of scientific knowledge, it makes sense to speculate whether those groups represent spaces for sharing and spreading ideas, concepts and parameters for scientific knowledge. To this end, our procedures were concentrated on the two largest components in the co-authorship network in order to reveal their knowledge structures, as organized from the co-citation of authors in selected periods (see Figures 4 and 5). It is worth pointing out that this procedure adds elements to the simple act of counting the most cited authors by each set of researchers because it constitutes a relational structure that links cited pairs, enabling interpretations as to how authors and texts are jointly articulated in the construction of knowledge ${ }^{6}$.

Figure 4: Co-citation networks for the main component
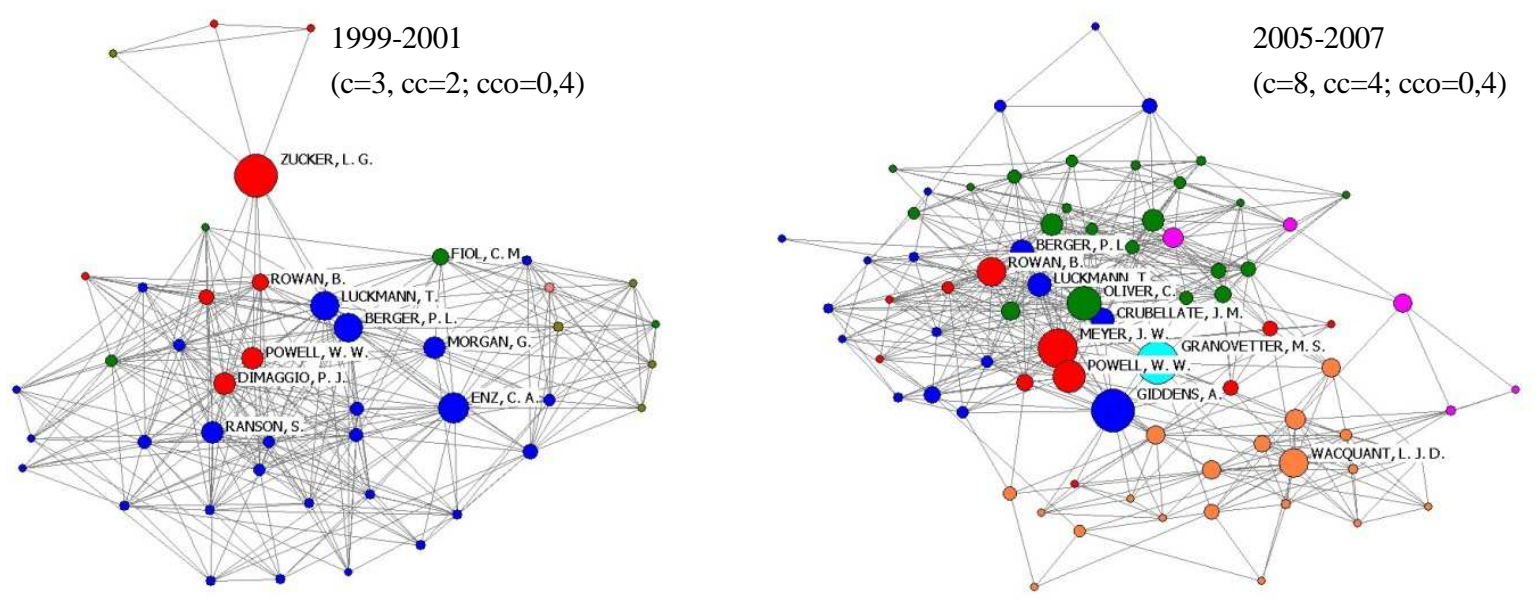

Source: research results.

Figure 5: Co-citation networks for the second largest component

1999-2001

$(\mathrm{c}=4, \mathrm{cc}=1 ; \mathrm{cco}=0,4)$
2005-2007

$(\mathrm{c}=4, \mathrm{cc}=3 ; \mathrm{cco}=0,4)$

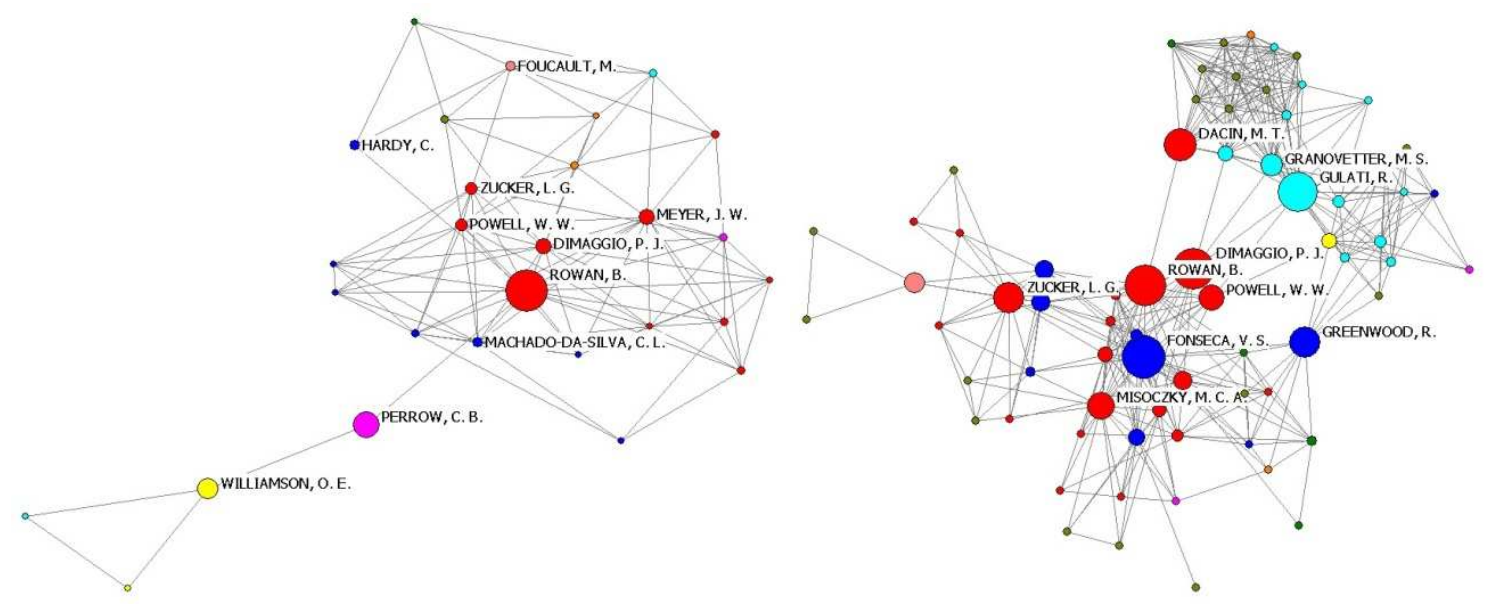

Source: research results.

The transformation of the intellectual structure of the main component can be seen in Figure 4. During the periods under study, the most traditional authors of the institutional perspective became more prominent while the field was becoming more integrated in the component. In the main component, the initial dialogue between approaches gradually ended up forming a basic nucleus that, in the later years, made connections with other perspectives. During this period, the approximation of the institutional theory with the social network analysis 
is highlighted. Similar movement can be seen in relation to the number of authors linked to structurationist approach. Because they are more centrally positioned, these authors tended to be used in the connections between the different knowledge domains used by this component.

Focusing on the second largest component, from 1999-2001, the authors considered classic in studies in which the institutional approach is the predominant analytical perspective appear in the center in the co-authorship network. The ties in blue are cited authors who correspond to researchers in the main component, whose published works also appear with some emphasis. In the upper part of the figure it is important to note that there are a number of co-citation groups whose authors have been linked to the institutional perspective as specifically dealt with in this component. Pierre Bourdieu stands out in studies concerning social fields and Michel Foucault and Stewart Clegg in discussions concerning dependencies of power in the approach.

In the following years, these aspects continued to take shape and in the period from 2005-2007 two sets of references converge in the foundation of part of the works of this component: one is more central, including the authors who are seen as classic in the institutional perspective in organizations, in addition to the researchers from the same component and, further to the right, is a set of cited authors especially linked to interorganizational relationships.

Therefore, the data allowed us to conclude that, despite the widespread sharing of references between components, this did not preclude their capacity to adopt an identity of their own concerning their preferential basis for theoretical foundation. The two largest components differ from one another in terms of their articulation of the institutional perspective and also the popularity and prominence of authors and cited works. Finally, these characteristics proved to be very homogenous, although not perfectly so within the components. This shows a relatively high rate of internal convergence and brings them closer, with limitations, to their characterization as a group. Nevertheless, so far, it appears more prudent to say only that from their theoretical framework, the components followed a pathway of intellectual delimitation that distinguishes them from one another.

A further point that deserves to be mentioned concerning the two larger components is the fact that they have high rates of self-citation while the percentage of citations among themselves is quite low. The rate is over $70 \%$ for the second component and $90 \%$ for the first in terms of citations for researchers in their group in relation to the total number of researchers in the five largest components of the social co-authorship network. Another interesting aspect is that, in the main component, three of the most widely read authors are members of their own co-authorship network: Machado-da-Silva, Fonseca and Crubellate are cited respectively in 82.0\%, 78.0\% and $60.0 \%$ of the articles produced by this same component during the period under analysis. However, two of these authors are not even mentioned among the authors who are proportionally most cited or widely read in the second largest component. The exception is Fonseca, but even so with a more modest level of popularity in published works $(37.04 \%)$, in relation to the main component.

The reverse is also true. Three researchers from the second largest component are among the most widely cited by articles produced in their own co-authorship network. Vieira, Carvalho and Misoczky are found respectively in $55.56 \%, 51.85 \%$ and $33.33 \%$ of the articles published at this time; however, when we look at the main component, they appear far less often and are not among the most cited or widely read.

The data obtained from these analyses for the two largest components of the co-authorship network reveal a certain level of specificity in the cognitive structures of each, suggesting that it is possible to understand them as separate units, with social and intellectual features of their own. The connections between specific aspects of the intellectual base subjacent to each one of them reveal preferences of the researchers in each component, which results in a distinctive profile concerning how the institutional perspective is used for the analysis of organizational phenomena. It is believed that through a qualitative study of the content, these aspects could be examined further and reveal with greater clarity the scope of differences or divergences between ontological, epistemological and thematic assumptions within or between different groups of researchers. 


\section{Relationship between the social and the intellectual}

The comparison between the two largest components concerning the formation of their intellectual base allows us to state that, despite sharing certain elements, both were constructed differently, and this gives them a configuration of their own. Figure 6 illustrates this aspect through continuant researchers, associating the origin of the two largest components of co-authorship with advising relationships at the Doctorate and Master's Degree levels. It is interesting to note that, despite the original guidance relationship, both components developed separately, which may indicate different preferences concerning how to approach the organizational phenomenon in the light of institutionalism.

\section{Figure 6: Relationship between continuant researchers}

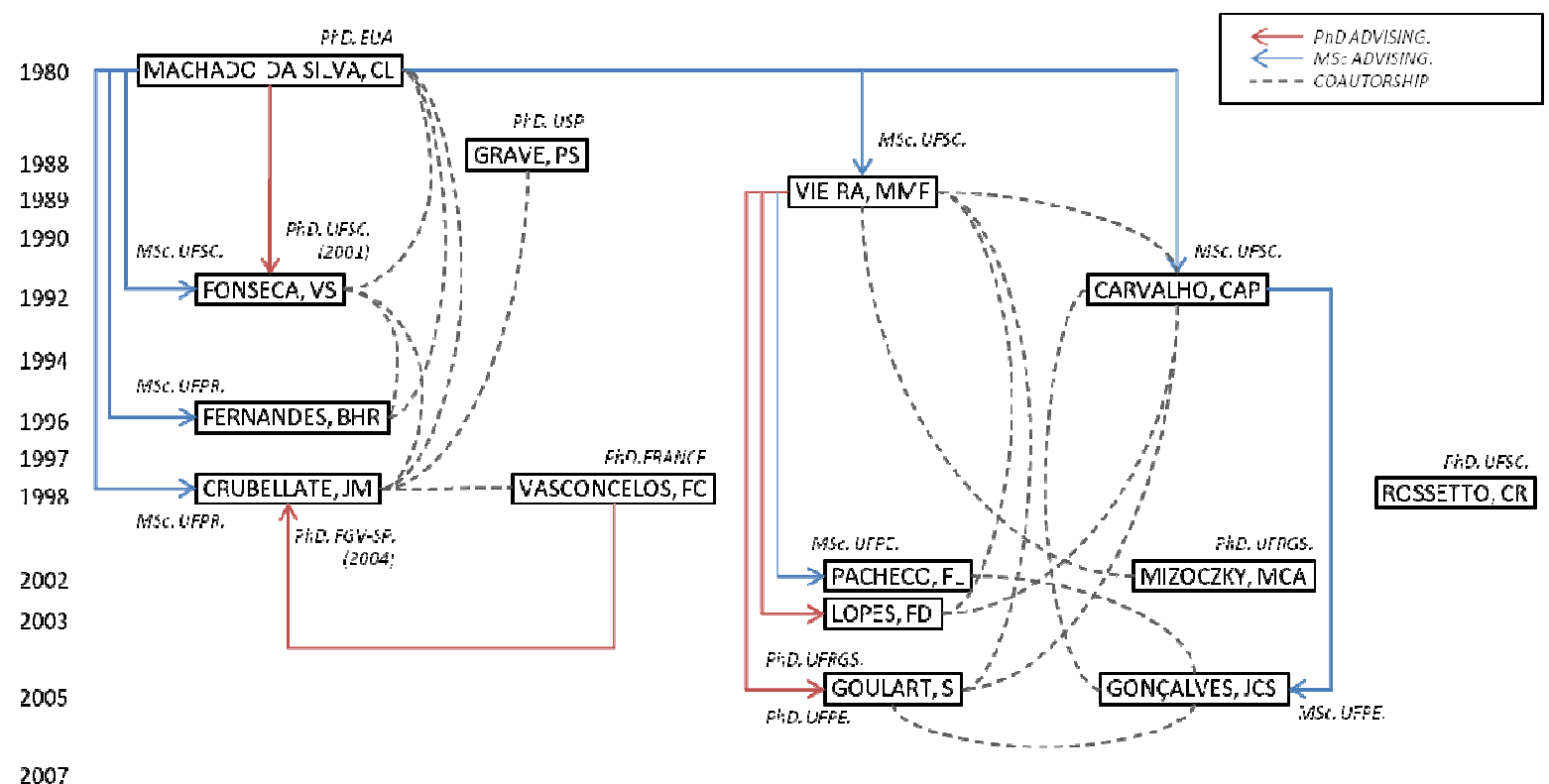

Note: the co-authorship ties are for 1993-2007.

Source: research results, based on data available from the Lattes Platform (GUARIDO FILHO; MACHADO-DA-SILVA;

GONÇALVES, 2009).

In order to evaluate this matter, we sought to explore further the relationship between the social and intellectual dimensions. As shown in the methodological procedures section, we once again used the network analysis for this purpose, but in this case our aim was to relate the researchers according to their similarity in terms of the references they used in their works. Thus, the ties of the network do not represent co-authorship relations but rather the similarity of the set of cited authors. Nevertheless, for easier viewing, we applied different colors to the nodes depending on the component of the social network in which each researcher is included. The resulting network shows the intellectual affinity among researchers.

As showed in Figure 7, researchers with different citation profiles are represented by nodes that are distant from each other; the more distant, the more different the researchers are in terms of what they cite. Conversely, the closer the nodes are to each other, the more similar the researchers are in terms of their citation profile. In this case, the proximity of researchers would reveal natural communities, i.e., sets of researchers who share the same intellectual basis whether or not they are directly connected for scientific production. The relevant point here is the evidence of a strong correlation between these natural communities and co-authorship components, as was shown in the co-authorship network. Statistical techniques back up these results. 


\section{Figure 7 : Similarity of researchers based on the references they cite}

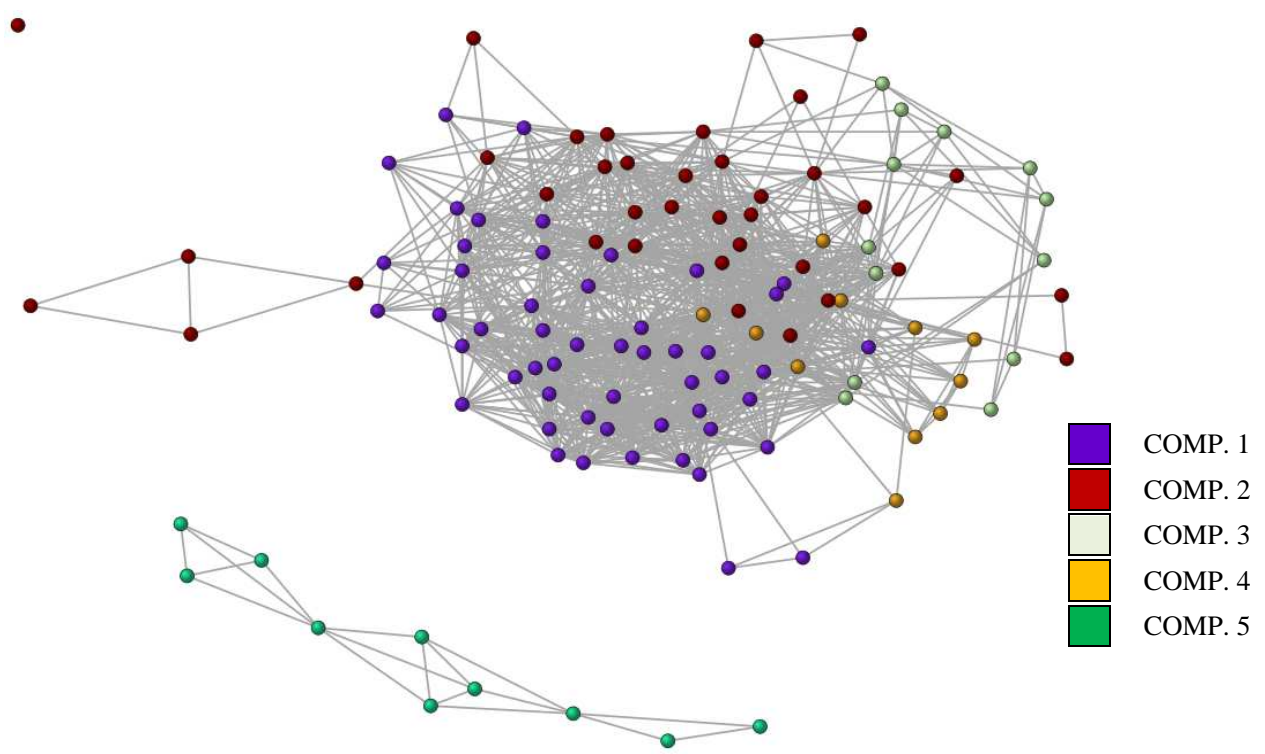

Note: To facilitate viewing of the network, only ties that represent higher degrees of similarity are shown (>0.3). For the same reason, researchers who belong to peripheral components have also been excluded, with only members of the five largest components remaining.

Source: research results.

This finding shows that there is a close relationship between the social and intellectual dimensions in the field under study, so much so that the results were confirmed and strengthened by the E-I Index and MRQAP statistical tests. The former jointly evaluates the degree to which connections between researchers in the intellectual affinity network occur with other members of the same component. The results show that the ties tend to concentrate internally within the components (E-I Index $=-0.214, \mathrm{p}<0.05$ ), which appears to emphasize the idea that relationships in a component tend to influence the knowledge framework used as a basis in studies and also that the cognitive structure of a component is more likely to serve as a theoretical foundation than theoretical frameworks that are predominant in other parts of the field. Meanwhile, the latter statistical procedure evaluates the direct relationships in the citation profile of researchers. The results show that the strength of intellectual affinity tends to be greater the higher the frequency of collaboration between the researchers $\left(\mathrm{R}^{2}=0.176, \mathrm{p}<0.001\right)$, revealing the considerable influence of dyadic relationships in the theoretical foundation adopted by researchers.

\section{Discussion: social mechanisms}

The results so far allow us to conclude that co-authorship relations, besides showing evident links between researchers in terms of collaboration, also reflect social processes that extrapolate the dyadic relationship between actors. In other words, although it is evident that in co-authorship relationships researchers share common reference frameworks, the results of this work show a structural dimension in terms of shared understandings that overlap the direct ties between them and that do not depend on them directly. On the one hand, this brings us back to socialization processes, involved in the researchers' intellectual formation process; on the other hand, the findings are linked to the intellectual delimitation itself, favoring a particular perspective, homogenizing the intellectual structure and conforming to social and symbolic frontiers. With this in mind, we dedicated this section to the discussion of the results found in light of social mechanisms that can be helpful when it comes to understanding the construction of scientific knowledge.

Thus, we conducted the interpretative analysis of the set of information found so far, attributing to it a meaning based on three types of social mechanisms: relational, cognitive, and political/intellectual. We would like to 
make it clear that the separating these is highly complex and an attempt to do so didactically will result in some redundancy throughout the text since the relational structures are also processes of communicative interaction between researchers, culturally constituted and not merely conductors or a locus of information (MISCHE, 2003).

\section{Cognitive mechanisms}

The first aspect worth mentioning has to do with recognizing articles as symbolic elements. They are not conceptions reduced to what is written because they carry widely shared beliefs, values and ideas in how scientific knowledge might be organized and communicated (SCOTT, 2003). According to Giddens (1987), articles are better understood as social practices. As such, they are consumed and, therefore, continually interpreted and modified throughout the process of transmission of ideas.

Nevertheless, we agree with Strang and Meyer (1994) that this process is not dealt with mechanically, with ideas flowing directly by way of social relationships. We are dealing with theorization processes in that while ideas are interpreted and cognitively organized, they are also diffused and articulated in broader schema of meaning. These in their turn serve as parameters for capturing knowledge. In this sense, the theorization occurs under the ongoing knowledge construction and how it is being coded, abstracted and converted into shared interpretation schema. Furthermore, it is also applied to the researchers themselves in that they begin to perceive themselves and be perceived by others as similar.

The notion of similarity developed by Strang and Meyer (1994) has to do with the degree to which shared understandings are perceived by researchers in relation to what is practiced in a certain field, thus serving as a guide for the diffusion of ideas, either by giving continuity to that which is perceived as a suitable model or by social embeddedness. In this sense, it can account, albeit partially, for the fact that the components, especially the two largest, have different intellectual structures, with different degrees of involvement of certain cited works and authors. Each has its own theoretical framework, in which ontological, and epistemological preferences would be supported, suggesting shared understandings among the members of each components concerning how organizational phenomena can be understood from the institutional perspective.

However, although similarity may be associated with social relationships and the intellectual structure, this does not allow us to consider the commitment of researchers to the perspective for which they follow. This is now a question of solidarity, which has to do with intellectual strengthening and the tendency towards embeddedness identified in the field or in part of it. The research results show this, especially when a low degree of crossed citations between the two largest components was found, along with a significantly high volume of self-citations. The question of solidarity may also explain the negative E-I Index concerning the propensity of relationships inside the component. These aspects, therefore, are related to the local validation made evident by the knowledge generated by the component and how it is based.

Taken together, similarity and solidarity refer to the matter of social identification, i.e., a process by which a certain vision of the world, here having to do with how knowledge is articulated with organizational phenomena, gains an advantage over those with whom members of a certain community interact, defining a shared sense of reality (MACHADO-DA-SILVA; NOGUEIRA, 2001). This aspect refers to the results found through analysis of the intellectual affinity network, organized through the citation profiles of the researchers in each component, positioning them closely without any consideration of their social relationship, but proving the social influence in the formation of interpretative frameworks.

Thus, both aspects (similarity and solidarity) show a relationship with the diffusion of ideas, more specifically how the institutional perspective is articulated with organizational studies, which converges with the findings, from the uniquely mode of appropriation of the institutional theory through the largest components in the field. Thus, the finding that the intellectual structure of the field, or even its components, has been incorporated and combined theoretical elements, as represented in the co-citation networks, requires considerations about the processes of translation and bricolage (CAMPBELL, 2005), respectively, concerning the adjustment or combination of elements that configure the theoretical framework for the construction of knowledge. Treated in 
the same way, they appear to explain certain findings in that they lead to developments that involve not only the sharing of ideas but also normative aspects and interests.

Cognitive mechanisms, therefore, may involve intellectual preferences as to how the perspective should be organized, which accounts for the differences between the cognitive structures, the prominence and popularity of cited authors and texts in the components. According to our findings, the researchers articulate the knowledge in the field so as to reflect the way that they believe the understanding of organizational phenomena should be established in light of the institutional perspective. The incorporation of knowledge may involve an attempt to maintain a certain degree of identification among researchers, which was most visibly demonstrated within the components themselves, attributing to them the potential for embeddedness, combining new elements in the current structure, adjusting and changing, but without moving away from its fundamental cognitive base. This may also account for the fact that they remain different, even with the growth of the network. However, translation mechanisms throughout the knowledge construction processes may involve a debate over the academic recognition and legitimacy of the perspectives defended by different sets of researchers and by actors with greater power to influence scientific production. As will be seen, along with relational elements this aspect may help account for the fact that the development of the two larger components in the field occurred in parallel, defining not only social co-authorship boundaries but also the theoretical framework for producing works.

Finally, it could be argued that social connections take place due to intellectual affinity, an aspect justified by the idea of similarity discussed above. Although this hypothesis is highly plausible, we understand that it is not the primary mechanism in the social configuration of the co-authorship components. We believe that the social organization of the groups of researchers could occur through an approximation between them because they mutually recognize each other as similar in how they articulate knowledge, although our findings point to the role of continuant researchers in the reception of newcomers and their predominance in terms of production. Therefore, although the social configuration can to some extent be explained through similarity mechanisms, what the results show is also the presence of relational mechanisms, especially evident in the larger components.

\section{Relational mechanisms}

Concerning the aspects discussed so far, there are also relational implications, assuming that the connection between researchers refers to forms of co-authorship and mutual recognition, that go beyond any isolated act of scientific production. In this way, relational mechanisms have a widespread influence on the behavior of actors, either as channels for diffusing practices and perspectives or in how they mutually identify each other, or in the articulation of ideas for understanding organizational phenomena. In this sense, relational mechanisms may be associated to retaining knowledge in the field, involving its dissemination, legitimization and incorporation, in addition to the social organization itself as different intellectual groups.

As the research results show, there is a fragmented field, with five larger components, two of which stand out among the others, both in terms of number of researchers and the volume of articles produced during the period under study. We have previously discussed some aspects that might account for this formation, especially the fact that they remain distant, even though the field is growing. We concluded that this has to do with the processes of similarity and solidarity of these groups, which end up emphasizing their collective identity, defining them not only socially but intellectually. However, our findings also refer to the effects of characteristics of social relationships that support these processes, which means considering that the flow of the diffusion of ideas and the sharing of ideas does not occur haphazardly, but through social networks of researchers. These characteristics involve structures of preferential attachment and stratification, which influence the academic communication system.

Within the two largest components were structures characterized by the presence of certain researchers with a higher number of connections than the others, which put them in a better position to control the relational flow within the network, which also confers upon them greater influence on the dynamic of constructing the field. In both components, the most central authors are also continuants, and are also the ones who have been active longest in the field. Although there are variations concerning the differences between the structural 
characteristics of these components, it was evident that the growth of the field took place surrounding them. Different reasons can be given for this, as will be seen below.

The first reason has to do with the fact that because there are more central and continuant authors, this implies that they should be considered as forces of dissemination and legitimization of the knowledge of the field due to the social capital they have accumulated (ZUCKER; DARBY, 1996). As such, they may be concerned with cultivating relationships that can carry forward the intellectual developments in which they are involved. Less intentionally, the more central authors have a higher number of relationships, activating a wide range of contacts, which makes them appear more prominent or visible as an influential information channel (WASSERMAN; FAUST, 1994). Therefore, it could be said that researchers with these characteristics might be seen as leaders in that they promote the dissemination of ideas, mobilize structures and are behind the production of scientific knowledge.

Furthermore, according to Braun, Glanzel and Schubert (2001), continuants play an important role in the construction of knowledge, especially in the consolidation of production and articulation with other categories of authors, such as newcomers or transients. Moreover, continuants act as disseminators, maintaining a high degree of connectivity with other actors (WAGNER; LEYDESDORFF, 2005). Under these circumstances, their performance in the structuration of the field occurs through mechanisms of preferential attachment, which means that the relationships between researchers are unequally distributed, with higher concentration on the most prominent, which tends to underline their high degree of connectivity. Therefore, the idea of social stratification in co-authorship networks for scientific production, according to the findings of this study, allows us to believe in the more consistent performance of certain researchers in the structuration of components and, as a result, in the intellectual structure of the field. Researchers whose reputations stand out or who have access to resources such as experience or knowledge tend to be accessed more and, because of this, see an increase in their prestige at the same time as they also influence the knowledge that is produced (see MERTON, 1996 and MOODY, 2004). Both of these aspects appear to make sense in light of the results of this study.

It is worth noting that these same researchers also have greater betweenness centrality, a characteristic that is structurally linked to their potential control of interactions. In the situation under study, this means, on the one hand, dependence on the part of other authors and, on the other hand, their influence on the circulation of ideas in the field, considering that we are dealing with co-authorship networks of scientific works, which means the articulation of ideas.

Once again, this has to do with the probable influence of these authors on the cognitive structures. Central authors tend to spread their ideas more rapidly in the field and due to this increased visibility they tend to be consumed more than the others. This can be seen in the data concerning to what extent Brazilian researchers are represented in the references and their popularity in the field, especially within the components in which they are included.

The research results also show other situations in which relational mechanisms influence the intellectual structure. In this case, the structural characteristics of the social network, especially resulting from aspects of stratification and betweenness, have an influence on the reference base of the field, as found by the E-I Index and the MRQAP technique. At first sight, a new relationship in the component appears to suffer form the effect of embeddedness, i.e., existing relationships have a certain force in favor of promotion or intellectual alignment.

However, it is worth reflecting on the fact that existing relationships in the components are not isolated from the intellectual structure; on the contrary, they are supported by it, making sense and ensuring legitimacy for the favored perspective. For this reason, the effect of the embeddedness, resulted of the social relationships, cannot be understood in a linear fashion, from the social to the intellectual, but rather recursively, referring to the aforementioned cognitive mechanisms. Likewise, the diffusion of new ideas can also be viewed this way: if the construction of the institutional perspective receives new ideas, this means that they have been consumed and articulated with the knowledge in the field. As they are incorporated into new works, they also undergo a social evaluation, so that, if they are accepted, they can enjoy the existing co-authorship channels to carry on their diffusion. 
Relational mechanisms of betweenness and stratification may also encourage the consumption of certain ideas, favoring their acceptance and stimulating new research. These mechanisms may also be responsible for dissemination beyond the boundaries of the components, since the reputation that has been achieved by certain researchers, along with the fact that they are also more prolific, results in their becoming a reference base for the development of new works. On the other hand, they can also provide legitimacy for these studies, establishing a contact point with the corpus of knowledge already recognized and considered valid (VERGARA; CARVALHO JR., 1995; McKINLEY; MONE; MOON, 1999; OFORI-DANKWA; JULIAN, 2005). In other words, relational aspects can also influence a wide range of researchers through the resulting cognitive structure in the field, even if there are no social relationships among them. The findings in the intellectual affinity network and the degree of popularity achieved by certain texts and authors in the field as a whole can also be conditioned by this aspect. In this sense, it could be said that the formation of natural communities, in some cases, precedes co-authorship relationships.

\section{Political/intellectual mechanisms}

Political/Intellectual mechanisms are processes through which the construction of the institutional perspective occurred by way of intellectual debate for the recognition of knowledge claims concerning the most adequate way to interpret the phenomena in the field. In this sense, it involves the cognitive and relational aspects that have already been considered.

What has been dealt with so far has shown a fragmented field organized around two large components, i.e. two sets of researchers which have grown in parallel but not with equal representation in terms of number of articles published and the adhesion of members of the academic community. This segmentation of the social structure, in accordance with Diani (2003b), favors the intellectual debate in which the components, by abstaining from cooperation, can adopt a competitive stance between themselves. In such circumstances, on the one hand, does not seem contradictory to say that these components also form social and symbolic frontiers, defended by their members, since both have shown a close connection with perspectives, associated with intellectual leadership and mechanisms of stratification and solidarity. On the other hand, the intellectual choices of the components over time may also represent the competitive element in the field; they show that there are differences as to how to understand the institutional perspective in the context of organizational studies so as to minimize the chances of cooperation.

One of the developments concerning this aspect again has to do with theorization, more specifically with one particular cognitive mechanism that is commonly dealt with in the literature on social movements called framing (see BENFORD; SNOW, 2000 and CAMPBELL, 2005). This mechanism assumes that the dissemination of ideas does not occur neutrally but is mediated by interpretation schema that organizes knowledge in the sense of establishing the alignment between the perspectives of disseminators and receivers. More than this, as explained by Lounsbury, Ventresca and Hirsch (2003), frames refer to the contexts in which appropriate and shared models are constructed, closely linked to political action. In a more critical version, this type of mechanism may be understood as the use of discourse in favor of sectional interests, which would require qualitative content or discourse analysis procedures to examine these aspects. Nevertheless, broadly considered as a reflection of the conversational dynamic among actors, it may have a closer connection to the notion of institutional logic, as suggested by McAdam and Scott (2005), referring to collective interpretation and social construction processes linked to shared cognitive structures, but which are the opposite of other groups. In the latter sense, it is possible to establish a connection with the aspects that have been dealt with throughout this study.

The idea of framing as a mechanism for the construction of scientific knowledge in the institutional perspective in organizational studies can be expressed structurally by the parallel development of the two main components in this field of study. Each of them shows certain signs of internal homogeneity concerning the foundation of the knowledge they produce in articles, which might result from their epistemological preferences. Moreover, they showed a greater tendency to introspection, with reduced cross citation, citing themselves on a larger scale and emphasizing their intellectual structure through the embeddedness of their members. They also have been organized surrounding the oldest authors in the field, many of these classified as continuants, who could 
performed in the sense of guiding the understanding of their followers, as discussed in the section concerning relational mechanisms. In addition, this situation goes beyond the normative aspect associated with the internal theoretical framework of the component. It has to do with the defense of interests, involving rhetoric and discourse, which may be in favor of certain perspectives and may not legitimize others in the process of the construction of knowledge According to Merton (1996), being involved in science also means a pursuit of recognition and legitimacy in the scientific community, which rarely occurs without intellectual dispute (ASTLEY, 1985; WILLMOTT, 1993). The structural evidence we found favors the consideration of this aspect. Not that this should be understood as a pre-planned strategic action, but in the sense of intentionally promoting the dissemination of certain interpretative frameworks.

As we have seen, the social organization around the centrally positioned actors in co-authorship networks tends to promote them as a force of dissemination and legitimization in terms of the construction of the approach. In these circumstances, they can also be seen as generators of symbolic and material resources connected to scientific activity, especially through potentially assumed positions outside of the co-authorship network ${ }^{7}$, sometimes playing a political role in the field and, therefore, involving their co-authorship network.

In this sense, some additional developments may be inferred concerning the political articulation: (i) the coauthorship networks and the expression of their cognitive framework in the intellectual structure of the field can be seen as ways to promote reliability and acceptance of ideas by involving and stimulating greater sharing with consequences in terms of intellectual recognition, both for the researchers themselves and the perspective they support; (ii) there may be an influence in the impartial production of knowledge, stimulating academic disputes and the sometimes ideological defense of perspectives; (iii) the self-reference characteristics and the tendency towards embeddedness caused by relationships within the components might limit the circulation of ideas to restricted research circles, influencing combination or articulation with other interpretations produced externally, which may be undervalued or considered unsuitable, establishing a situation of intellectual enclosure. However, these aspects are merely theoretical possibilities that have yet to be investigated, so much so that the evidence resulting from research does not prove that they exist in the dynamic of the field.

\section{Conclusions}

In this study, we investigated the construction of scientific knowledge, focusing on the institutionalism in organizational studies in Brazil under the assumption that it is a recursive process between the social and intellectual dimensions, in which relational, cognitive and political/intellectual mechanisms are involved.

We chose to consider scientific production in the form of articles as a source of data for analysis because we recognize that articles are also symbolic elements in that they condense the language in the context of meaning of the agents (GUARIDO FILHO, 2008). As such, they are consumed and, therefore, continually interpreted and modified. Moreover, scientific articles express social practices, bearing widely shared values and beliefs regarding the processes of organization and communication of the scientific knowledge (GIDDENS, 1987; SCOTT, 2003).

Our major findings are summarized as follows:

Quantitative evolution in terms of researchers and articles: around 20\% a year, with higher levels of activity in recent years;

Elaboration of the social organization around the institutional perspective, with greater cooperation between researchers and the formation of co-authorship clusters, with the two largest being responsible for $34.7 \%$ of researchers and $57.6 \%$ of production for the period;

Intellectual consolidation in terms of knowledge structures (identifiable citation pattern and intellectual preferences) discernible in different social clusters;

Creative articulation of theory with acknowledgement of local researchers as valid references, and identifiable cognitive structures represented by idiosyncratic co-citation maps. 
The emphasis on certain social mechanisms as processes in the construction of the institutional perspective in organizational studies in Brazil has greatly highlighted aspects that have to do with the potential influence of certain actors, being intellectually articulated, intermediating relationships and guiding the way in which knowledge is produced or even the founding of cognitive frameworks that are disseminated in the field due to the influence of their reputation and productivity. Nevertheless, these considerations should not be understood disjointedly with more wide ranging knowledge since, it is highly unlikely that the construction of the field would be simply the result of deliberate actions. Thus the construction of the institutional perspective cannot be boiled down to the intentional actions of certain researchers of sets of researchers, although it could also depend on them.

It is worth emphasizing that the accumulation of knowledge is a social process and, therefore, the development of a theoretical perspective is connected to matters of conformity, with what is considered acceptable and desirable. The configurations of the intellectual structure, in this sense, imply reference frameworks for action, although they themselves are a product of preceding practices, reproduced through the dynamic of scientific production, and organized according to the collaboration networks. Therefore, although a theoretical approach can be defined paradigmatically in the context of its intellectual program as defined by the agents in the course of their scientific activity, our findings favor understanding them not as a packed model but one that is ongoing.

In these circumstances, it is important to bear in mind that knowledge in a specific field, as is the case of organizational studies, does not develop linearly and cannot be considered homogenously regarding intellectual interests, social relationships, symbolic recognition, etc. In this light, we believe that, as part of a social system in continuous (re)production, an analytical perspective such as the institutional theory in organizational studies can be understood diachronically as a movement in which intellectual interactions are in flux, recurrently influencing (and they themselves being influenced by) the reference system adopted by the actors during scientific production. Synchronically, however, at the agency level, an approach can be expressed in an intellectual debate. In this case, it is interesting to attend to the possibilities of active participation of researchers, competitively or cooperatively, in favor of preferred perspectives (with their own interpretation of organizational phenomena), with implications for the development of the field in the form of scientific production and legitimization of worldviews and also, indirectly, for the establishment of the boundaries of the field in question.

To conclude, one final point deserves to be mentioned concerning the discussion of the results in light of the social mechanisms. The option to interpret the empirical results based on cognitive, relational and political/intellectual processes has to do not with a concern over generalizing the results but rather the transferability of mechanisms in different situations or different fields. As these mechanisms have often been studied with a variety of implications, their use in this study allows us to advance beyond this particular case. Furthermore, the findings resulting form the research procedures should not be understood as faithful expressions of reality, running the risk of being limited to the formalism of the analyses. On the contrary, they need to be recognized as a collection of evidence which can help to explain the social process in that the use of mechanisms is seen as an analytical device (HEDSTROM; SWEDBERG, 1996; McADAM, 2003; TILLY, 2001). From what we have seen, therefore, we emphasize that although the inadequacy of the term may be misleading, the use of social mechanisms has noting to do with the establishment of causal relationships in a strict sense, despite reflecting the predominance of a design of an explanatory nature. There is, in fact, a concern over investigating and recognizing elements that are part of the social process of the structuration of scientific knowledge. 


\section{References}

ACEDO, F. et al. Co-authorship in management and organizational studies: an empirical and network analysis. Journal of Management Studies, v.43, n.5, p.957-983, 2006.

ASTLEY, W. G. Administrative science as socially constructed truth. Administrative Science Quarterly, v.30, n.4, p.497$513,1985$.

BARABASI, A. et al. Evolution of the social network of scientific collaborations. Physica A, v.311, n.3, p.590-614, 2002.

BENFORD, R. D.; SNOW, D. A. Framing process and social movements: an overview and assessment. Annual Review of Sociology, v.26, p.611-639, 2000.

BORGATTI, S. P. Centrality and network flow. Social Networks, v.27, n.1, p.55-71, 2005.

BRAUN, T.; GLÄNZEL, W.; SCHUBERT, A. Publication and cooperation patterns of the authors of neuroscience journals. Scientometrics, v.51, n.3, p.499-510, 2001.

CALDAS, M. P.; FACHIN, R. Paradigma funcionalista: desenvolvimento de teorias e institucionalismo nos anos 1980 e 1990. In: ; BERTERO, C. O. (Ed.). Teoria das organizações. São Paulo: Atlas, p.69-79, 2007.

CAMPBELL, J. L. Where do we stand? Common mechanisms in organizations and social movements research. In: DAVIS, G. F. et al (Ed.). Social movements and organization theory. New York: Cambridge University Press, p.41-68, 2005.

CHEN, C. Searching for intellectual turning points: progressive knowledge domain visualization. Proceedings of the National Academy of Sciences of the United States of America, v.101, sup.1, p.5303-5310, 2004.

. Information visualization: beyond the horizon. $2^{\text {nd }}$ ed. London: Springer, 2006.

; PAUL, R. J. Visualizing a knowledge domains intellectual structure. Computer, v.34, n.3, p.65-71, 2001.

CRONIN, B. The scholar's courtesy: the role of acknowledgement in the primary communication process. London: Taylor Graham, 1995.

Normative shaping of scientific practice: the magic of Merton. Scientometrics, v.60, n.1, p.41-46, 2004.

DEKKER, D.; KRACKHARDT, D.; SNIJDERS, T. A. B. Sensitivity of MRQAP tests to collinearity and autocorrelation conditions. Psychometrika, v.72, n.4, p.563-581, 2007.

DIANI, M. Introduction: social movements, contentious action, and social networks: "from metaphor to substance"? In: ; McADAM, D. (Ed.). Social movements and network. Oxford: Oxford University Press, p.1-18, 2003a.

. Networks and social movements: research programme. In: ; McADAM, D. (Ed.). Social movements and network. Oxford: Oxford University Press, p.299-319, $2003 \mathrm{~b}$.

FLIGSTEIN, N. Social skill and the theory of fields. Sociological Theory, v.19, n.2, p.105-125, 2001.

Fields, power, and social skill: a critical analysis of the new institutionalisms. International Public Management Review, v.9, n.1, p.227-252, 2008.

GIDDENS, A. The constitution of society. Cambridge: Polity Press, 1984.

Structuralism, post-structuralism and the production of culture. In: today. Stanford: Stanford University Press, p.195-223, 1987.

GORDON, A. Transient and continuant authors in a research field: the case of terrorism. Scientometrics, v.72, n.2, p.213224, 2007.

GUARIDO FILHO, E. R. A construção da teoria institucional nos estudos organizacionais no Brasil: o período 19932007. 2008. 301f. Doctoral dissertation (Doctorate in Management) - Universidade Federal do Paraná, Curitiba, 2008.

; MACHADO-DA-SILVA, C. L.; GONÇALVES, S. A. Organizational institutionalism in the academic field in Brazil: social dynamics and networks. Brazilian Administration Review, v.6, n.4, p.299-315, 2009.

ROSSONI, L. The social and intellectual dimensions in the construction of scientific knowledge: the institutional theory in organization studies in Brazil. Brazilian Administration Review, v.7, n.2, p.135-154, 2010.

HANNEMAN, R. A; RIDDLE, M. Introduction to social network methods. Riverside: University of California, 2005.

HEDSTROM, P.; SWEDBERG, R. Social mechanisms. Acta Sociologica, v.39, n.3, p.281-308, 1996. 
HIRSCH, J. E. An index to quantify an individual's scientific research output. Proceedings of the National Academy of Sciences of the United States of America, v.102, n.46, p.16569-16572, 2005.

KRACKHARDT, D.; STERN, R. Informal networks and organizational crises: an experimental simulation. Social Psychology Quarterly, v.51, n.2, p.123-140, 1988.

LEYDESDORFF, L. Theories of citation? Scientometrics, v.43, n.1, p.5-25, 1998.

. The challenge of scientometrics: the development, and self-organization of scientific communications. $2^{\text {nd }}$ ed. USA: Universal Publishers, 2001.

LI-CHUN, Y. et al. Connection and stratification in research collaboration: an analysis of the Collnet network. Information Processing \& Management, v.42, n.6, p.1599-1613, 2006.

LIU, X. et al. Co-authorship networks in the digital library research community. Information Processing \& Management, v.41, n.6, p.1462-1480, 2005.

LOUNSBURY, M.; VENTRESCA, M.; HIRSCH, P. Social movements, field frames and industry emergence: a culturalpolitical perspective on US recycling. Socio-Economic Review, v.1, n.1, p.71-104, 2003.

MACHADO-DA-SILVA, C. L. Modelos burocrático e político e estrutura organizacional de universidades. In: NUPEAU/UFSC. (Ed.). Temas de administração universitária. Florianópolis: UFSC, p.78-90, 1991.

; FONSECA, V. S.; CRUBELLATE, J. M. Estrutura, agência e interpretação: elementos para uma abordagem recursiva do processo de institucionalização. Revista de Administração Contemporânea, v.9, Special Edition 1, p.9-39, 2005.

; NOGUEIRA, E. E. S. Identidade organizacional: um caso de manutenção, outro de mudança. Revista de Administração Contemporânea, v.5, Special Edition 1, p.35-58, 2001.

; ROSSONI, L. Persistência e mudança de temas na estruturação do campo científico da estratégia em organizações no Brasil. Revista de Administração Contemporânea, v.11, n.4, p.33-58, 2007.

McADAM, D. Beyond structural analysis: toward a more dynamic understanding of social movements. In: DIANI, M.; McADAM, D. (Ed.). Social movements and network Oxford: Oxford University Press, p.281-298, 2003.

; SCOTT, W. R. Organizations and movements. In: DAVIS, G. F. et al (Ed.). Social movements and organization theory. New York: Cambridge University Press, p.4-40, 2005.

McKINLE, Y. W.; MONE, M.; MOON, G. Determinants and development of schools in organization theory. Academy of Management Review, v.24, n.4, p.634-648, 1999.

MERTON, R. K. Priorities in scientific discovery: a chapter in the sociology of science. American Sociological Review, v.22, n.6, p.635-659, 1957.

On social structure and science. Chicago: Chicago University Press, 1996.

MISCHE, A. Cross-talk in movements: reconceiving the culture-network link. In: M. DIANI; McADAM, D. (Ed.). Social movements and network. Oxford: Oxford University Press, . p.258-280, 2003.

MOODY, J. The structure of a social science collaboration network: disciplinary cohesion from 1963 to 1999 . American Sociological Review, v.69, n.2, p.213-238, 2004.

MOYA-ANEGON, F. et al. Visualización y análisis de la estructura científica española: ISI Web of science 1990-2005. EI Professional de la Información, v.15, n.4, p.258-269, 2006.

MULLINS, N.C. Theories and theory groups in contemporary American sociology. London: Harper \& Row, 1973.

NEWMAN, M. E. J. The structure of scientific collaboration networks. Proceedings of the National Academy of Sciences of the United States of America v.98, n.2, p.404-409, 2001a.

Scientific collaboration networks I: network construction and fundamental results. Physical Review E, v.64, n.1, p.1-8, 2001b.

OFORI-DANKWA, J.; JULIAN, S. D. From thought to theory to school: the role of contextual factors in the evolution of schools of management theory. Organization Studies, v.26, n.9, p.1307-1329, 2005.

OTTE, E.; ROUSSEAU, R. Social network analysis: a powerful strategy, also for the information sciences. Journal of Information Science, v.28, n.6, p.441-453, 2002. 
READER, D.; WATKINS, D. The social and collaborative nature o entrepreneurship scholarship: a co-citation and perceptual analysis. Entrepreneurship theory and practice, v.30, n.36, p.417-441, 2006.

ROSSONI, L.; GUARIDO FILHO, E. R. Cooperação interinstitucional no campo da pesquisa em estratégia. Revista de Administração de Empresas, v.47, n.4, p.74-87, 2007.

Cooperação entre programas de pós-graduação em administração no Brasil: evidências estruturais em quatro áreas temáticas. Revista de Administração Contemporânea, v.13, n.3, p.366-390, 2009.

; MACHADO-DA-SILVA, C. L. Centralidade, produtividade e escolha preferencial: o papel da agência na construção do conhecimento científico em organizações e estratégia no Brasil. In: ENCONTRO DE ESTUDOS ORGANIZACIONAIS, 5., 2008, Belo Horizonte. Proceedings... Belo Horizonte: Anpad, 2008.

SCOTT, W. R. Institutional carriers: reviewing modes of transporting ideas over time and space and considering their consequences. Industrial and Corporate Change, v.12, n.4, p.879-894, 2003.

SMALL, H. Co-citation in the scientific literature: a new measure of the relationship between two documents. Journal of the American Society for Information Science, v.24, n.4, p.265-269, 1973.

Cited documents as concept symbols. Social Studies of Science, v.8, n.3, p.327-340, 1978.

2004.

. On the shoulders of Robert Merton: towards a normative theory of citation. Scientometrics, v.60, n.1, p.71-79,

STRANG, D.; MEYER, J. W. Institutional conditions for diffusion. In: SCOTT, W. R. MEYER, J. W. (Ed.). Institutional environments and organizations: structural complexity and individualism. Thousand Oaks: Sage, p.100-112, 1994.

TILLY, C. Historical analysis of political processes. In: TURNER, J. (Ed.). Handbook of sociological theory. New York: Springer, p.567-588, 2001.

VAN RAAN, A. F. J. Scientometrics: state-of-the-art. Scientometrics, v.38, n.1, p.205-218, 1997.

VARGAS-QUESEDA, B.; MOYA-ANEGÓN, F. Visualizing the structure of science, New York: Springer, 2007.

VERGARA, S. C.; CARVALHO JR, D. S. Nacionalidade dos autores referenciados na literatura brasileira sobre organizações. In: ENCONTRO NACIONAL DA ANPAD, 19., 1995, João Pessoa. Proceedings... João Pessoa: Anpad, 1995.

WAGNER, C. S.; LEYDESDORFF, L. Network structure, self-organization, and the growth of international collaboration in science. Research Policy, v.34, n.10, p.1608-1618, 2005.

WASSERMAN, S.; FAUST, K. Social network analysis: methods and applications. Cambridge: Cambridge University Press, 1994.

WILLMOTT, H. Breaking the paradigm mentality. Organization Studies, v.14, n.5, p.681-719, 1993.

ZUCKER, L. G.; DARBY, M. R. Star scientists and institutional transformation: patterns of invention and innovation in the formation of the biotechnology industry. Proceedings of the National Academy of Sciences of the United States of America, v.93, n.23, p.12709-12719, 1996.

\footnotetext{
${ }^{1}$ Cited by Cronin (1995, p.10).

${ }^{2}$ Organizational institutionalism as an analytical perspective was effectively launched in Brazil in a study conducted by Machado-da-Silva in 1991, according to Caldas and Fachin (2007). However, this work was not included in the analyses for this article as it had not been published among the sources selected for data collection.

${ }^{3}$ The following sources were used for this study: Revista de Administração de Empresas (RAE), Revista de Administração de Empresas Eletrônica (RAE-E), Revista de Administração da Universidade de São Paulo (RAUSP), Revista de Administração Contemporânea (RAC), Revista de Administração Contemporânea Eletrônica (RAC-E), Revista de Administração Pública (RAP), Organizações \& Sociedade (O\&S), Revista Eletrônica de Administração (REAd), Revista BASE, Cadernos EBAPE.br, Revista de Administração Mackenzie (RAM), Brazilian Administration Review (BAR), Annals of the Brazilian Academy of Management Meeting (EnANPAD), Annals of the Brazilian Organizational Studies Meeting (EnEO) and Annals of the Brazilian Organizational Strategy Meeting (3Es). The journals that were evaluated for 2007 were limited to those available up to the date when data collection ceased, with the last editions to be consulted being : RAE-E, 6(2); RAE, 47(4); RAP, 41(5); Cadernos EBAPE, 5(4); RAC, 11(4); RAC-E, 1(3); BAR, 4(3); RAUSP, 42(4); READ, 13(3); RAM, 8(4); BASE, 4(3); O\&S, 14(2).
} 
${ }^{4}$ The measurement used for correlating citations was the cosine, in accordance with Chen (2006), highlighting its suitability for studies like this one.

${ }^{5}$ The statistical analysis of the degree of centrality of the researchers revealed a preferential choice for continuants, i.e., they attracted a significantly higher number of collaborators than most of the others. This also shows their tendency to guide entrants in the field, resulting in their concentrating an increasingly higher number of collaborators in the network (NEWMAN, 2001a). The test to adjust to the power function was significant $(p<0.001)$ with a high coefficient of determination $\left(R^{2}=0.812\right)$ and exponent -1.78 .

${ }^{6}$ Further information on the comparison of the components can be found in Guarido Filho (2008).

Such as the status of the researcher in academic circles, his position in the groups and organizations pertaining to the field of organizational studies such as roles as a coordinator in research programs or an editor of a periodical or member of a regulating body such as Brazilian Academy of Management [Anpad] and its academic divisions, Brazilian Governmental Accreditation Agency of Graduate Programs [CAPES] or the Brazilian Agency for Scientific and Technological Development [CNPq]. 